\title{
MODERNITY AND CHANGING CULTURAL PATTERNS IN PAKISTAN
} Sidra Noreen ${ }^{1 *}$, Izhar Ahmad Khan ${ }^{2}$, Farkhanada Anjum $^{3}$, Ejaz Ashraf ${ }^{4}$

${ }^{1 *}$ Ph.D., Scholar, Department of Sociology, University of Agriculture Faisalabad, Pakistan; ${ }^{2,4}$ Associate Professor, Department of Sociology, University of Agriculture, Faisalabad, Pakistan; ${ }^{3}$ Assistant Professor, Department of Sociology, University of Agriculture Faisalabad, Pakistan. Email: *sidrasiyan@ymail.com

\author{
Article History: Received on $2^{\text {nd }}$ May 2021, Revised on $11^{\text {th }}$ May 2021, Published on $13^{\text {th }}$ May 2021
}

\begin{abstract}
Purpose of the Study: The present study is intended to determine the level of modernity and cultural change among university students. In addition, the study is also aimed to calculate the relationship between modernity and cultural change.

Methodology: Sequential mixed-method research approach is deployed in this study. Initially, the researcher used a quantitative research approach and surveyed the students using a cross-sectional survey design. A two-stage probability sampling technique was used, and a total of 420 students were selected using the stratified sampling technique and simple random sampling technique, respectively. Data were analyzed using SPSS 25 version.

Principal Findings: The results indicated that modernity and cultural change is not uniform among the respondents, but they varied as per the socio-demographic characteristics of the respondents. However, it is more visible in the material aspect of life than the non-material aspect of the social life among the students. In addition, results also indicated a positive relationship between modernity and changing culture among students.
\end{abstract}

Applications of the study: The results and findings of the study draw the attention of policymakers and researchers to take necessary steps to increase the benefits of modernity and cultural change and decrease the negative consequences of modernity and cultural change. Special measures are needed to protect local indigenous culture as well.

Novelty/Originality of this Study: The contribution of this study is a university student and modernity in changing values most prominent tool that makes us able to survive in society is cultural patterns through which we learn all that we need to survive and learn behavior, norms, customs repetition of acceptable action, etc. In the nineteenth century, modernization involves culture, and hence it is clear that modern tends are changing old ties of culture.

Keywords: Modernity, Cultural Patterns, Industrialization, Westernization, Society.

\section{INTRODUCTION}

Culture plays a vital part in the survival of every society. Culture is like software, and society is hardware. Culture is everything, even our behavior, our interaction everything is culture. Culture is a primary condition for society. The most prominent tool that makes us survive in society is cultural patterns. We learn all that we need to survive and learn behavior, norms, customs, repetition of acceptable action, etc. From religion to education, making friends, to getting a job, we learn through existing culture. It is the culture that makes us social human beings. Culture is an integral part of society. In the nineteenth century, modernization involves culture, and it made a precise prediction about the upcoming of business class, highlighting the increase of wisdom and the failure of belief (Cui \& Ryan, 2011).

In the twentieth century, the traditional society was hoping to leave their traditional cultures and reflected the West's western and technically "high" ways. Youth life experiences have been essential in modern society. This change affects relationships with family and friends, education and social settings, recreation and lifestyle, and the ability to establish new young adults. Many of these changes directly result from culture restoration, increasing demand for educated people. As a result of these changes, young people today have to negotiate a set of largely unknown risks to their ancestors (Inglehart and Baker, 2000). Modernity is a comprehensive concept that includes social, cultural, economic, and political dimensions. This implies that modernity is not a cross-cutting concept that is only linked to one thing but is linked to many other dimensions (Ullah,2020).

This modernity led by globalization affected each country's country regardless of socioeconomic status. They are more concerned about teamwork and put less attention on the ascribed status of the people. They are more concerned about the achieved status and roles attached to these achieved statuses (Hashim, Ullah, Khan, 2017).

It is also believed that modernized individuals also focus on modern scientific thoughts and practices. They are more reality-oriented and trust their senses more than abstract thoughts and faith (Khan \& Ullah, 2021).

It means that modern values change both maternal and non-material cultural patterns in many countries. In addition, modernity, regardless of its causes, decreases indigenous cultural values and increases global values that are part of modernized countries. There are many factors of modernization/westernization in Pakistan. However, it rapidly increased after the 1990s in Pakistan. There are two major global factors behind this rapid modernization. First of all, the end of the Cold War makes the world more global and open in terms of frequent interaction between the masses, and second privatization and democracy. In addition, the end of Zia's regime also played a vital role in increasing the adoption of 
modern western values. However, factors of modernization are beyond the scope of this study.

Still, the primary driving force is globalization behind modernization and westernization (Kakar et al., 2011; Inglehart and Baker, 2000; Ullah,2020). Modernization had changed Pakistan's society in many ways. People are using technology in every field of life, from agriculture to industry, from education to employment, from teaching to learning. In a nutshell, everyone uses imported electronic gadgets as they are used in developed nations like in European countries, i.e., UK, Germany, France, etc. This implies that Pakistanis are also using culturally diffused electronic and electric gadgets (Kazmi and Quran, 2005). Globalization and global thinking are among the significant factors behind many maternal and non-material cultural changes in Pakistan (Habib, 2018). Modernization had also affected the government. Recently, the government also passed a bill to stop violence against women. This implies that institutions at the macro level are also changing because of the modernization of the people. In addition, now governments are also working on global issues like climate change, poverty, women empowerment, and equality. Increasing awareness about global issues is because of increasing information sharing and knowledge based on modern western values and practices (Khan \& Ullah, 2021; Malik et al., 2020). Modernization increased insecurity and confusion among the masses. It also increased segmentation in society and increased the gap between the elite class, middle class, and lower class in terms of modernization. Moreover, it also increases differentiation based on religious values, cultural values, and modern values (Bauman, 2013; Willis, 2003).

\section{NEED OF THE STUDY}

In light of the facts mentioned above, it is necessary to examine modernity and change cultural patterns in Pakistan because most people and organizations are unaware of modernity cultural change in Pakistan. Furthermore, at the government level, the policymakers are not devoting due consideration to initiate significant steps to enhance the benefits of modernity and cultural change and mitigate modernity and cultural change outcomes.

\section{OBJECTIVES}

This study is conducted to determine the level of modernity and cultural transformation among university students in Pakistan. In addition, this study measures the association between modernity and cultural change in the context of Pakistan.

\section{LITERATURE REVIEW}

Globalization which leads to modernization inserts new trends and new technologies in developing societies (Amin, 2014; Khan, Ullah, Usman, Malik, Khan, 2020). Developing societies are also now practicing new technology in education, health, and the economy (Beck, 2018). In addition, diversity and respect for global values are also higher in developing societies nowadays. This implies that modernity is closely linked to globalization (Cook,2005). globalization not only changing the policies of the government but it is also changing the attitude and behavior at the individual level. For example, globalization is also changing parents' attitudes, and now parents are more concerned about their children's education. Parents educate their children to place them as productive citizens in the global economy. The government is also found very serious in this regard. The schools and teachers face a significant amount of pressure to ensure universal enrollment and provide quality education. These efforts at both state and individual levels fulfil two significant concepts of globalization, i.e., neoliberalism and capitalistic expansion. Therefore, it is a compulsion for the teachers to introduce and develop those skills among the students required in the global economic market (Khan, 2014; Torres, 2002).

Globalization is also forcing the relevant stakeholders to introduce many new interventions for increasing enrollment and quality education for the students. This implies that globalization is affecting the world's educational system in many ways. One of the components is introducing new methodologies and technology in classrooms for improving quality education. In addition, globally approved pedagogy skills are being provided to teachers for increasing their productivity in schools. These interventions had increased productively because now teachers use innovative methodologies and teaching methods.

On the other hand, teachers and students can now access resources worldwide using technology, i.e., internet connection and personal computers. It is now easy to access educational websites and use different learning software, e-books, and printed materials publicly available to the masses. This implies that computer-based learning increases with the passage of day with the innovation of mobile applications and pads (Khan, 2014; Hamid and Honan, 2012).

The most vulnerable group in this regard is the educated urban segment of Pakistani society. This vulnerable segment of the society is the elite class who spend a very lavish life. They practice modern western values and practices, but they are forcing the middle and lower class to copy them (Bottomore, 2006).

Everyone wants to be labialized a modern person from his/her dressing and physical appearance. The use of jeans and pants and shirt is increasing day by day. However, modern western dressing started from the urbanized community in the country that diffused to rural settings (Maqsood, 2014; Ullah,2020).

Many fast-food restaurants provide fast food, and the number of these restaurants is increasing day by day (Hussain, Zulfiqar \& Saboor, 2014). Therefore, none of the definitions of culture is wrong. In the current study, the researcher 
conceptualized culture as a set of ideas, norms, and behavior typical to groups of people who live in a specific geographical area (Varnum \& Grossmann, 2017).

Collins, Castro, and Ryan (2016) conducted their study to elaborate on Westernization, Confucianism, economization, and globalization with higher education. In their study, they believed that these four concepts are the key driver of higher education. They further added that Western knowledge remained dominated in higher education because of the expansion of Western knowledge and discourse across countries because of the early colonization of the world by different western countries, i.e., the UK.

In the definition of globalization, it was evident that sharing knowledge and ideas across the border also came under the broader dimensions of globalization. Consequently, the forces of globalization are forcing many institutions to work in close relations with other institutions to operate from a global perspective. This involvement of educations institutions brings a tremendous amount of international involvement in the world, and it is connecting many researchers and academicians regardless of the borders (Altbach \& Knight, 2007; Hashim, Ullah, Khan, 2017).

This is evident from the contemporary high demand for education in Pakistan and the involvement of private sector educational institutions to provide education to the masses. As a result, access to higher education increased in many Asian countries (Lee, 2011Marginson,2011). It is pertinent to explain the difference between the cultures and cultural values of Eastern and Western parts of the world. In the Eastern part of the world, people focus on group and group dynamics. On the other hand, in Western culture, the focus is upon the individual and his/her desires (Triandis, 2018).

Modern usages of food or dietary pattern include a high level of meat consumption in red meat and processed meat. In addition, modern or western food also includes a higher level of refined grains, sugar in the form of additive sugar, refined and processed dairy products, cheese, desserts, processed and high energy and processed drinks, and whole grains, fruits, etc. This implies many modern western food items include processed and refined items (Astrup et al., 2011).

In the definition of globalization, it is apparent that sharing knowledge and ideas across the border also came under the broader dimensions of globalization. Consequently, the forces of globalization are forcing many institutions to work in close relations with other institutions to operate from a global perspective. This involvement of educations institutions brings a tremendous amount of international involvement in the world, and it is connecting many researchers and academicians regardless of the borders (Altbach and Knight, 2007). However, for increasing interaction between educational institutions, the role of globalization is very different from the role of modernization/ westernization. Globalization is more a catalyst that increases interaction between institutions of the world like educational institutions. It is a driving force that brings institutions closer with the help of a modern communication system, transportation, interaction, and engagement (Neubauer, 2013).

\section{HYPOTHESES}

$\mathbf{H}_{1}$ : Higher the level of modernity higher will be the level of western influence.

\section{METHODOLOGY}

The total sample size (420) was equally proportionated in public sector universities. The researcher used a sequential mixed method research approach in the present study. Initially, the researcher used a quantitative researcher approach and surveyed the students using a cross-sectional survey design. For this purpose, students were selected from two universities, i.e., Agriculture University, Faisalabad, and University of the Punjab, Lahore. A two-stage probability sampling technique was used, and a total of 420 students were selected using the stratified sampling technique and simple random sampling technique, respectively. Data was collecting using a modified standard tool of data collection.

\section{RESULTS AND DISCUSSION}

Table 1: Modernity and westernization is gradually changing cultural patterns

\begin{tabular}{lll}
\hline Change & Frequency & Percentage \\
\hline Strongly disagree & 35 & 8.5 \\
\hline Disagree & 38 & 9.2 \\
\hline Agree & 139 & 33.8 \\
\hline Strongly agree & 199 & 48.4 \\
\hline Total & 411 & 100.0 \\
\hline
\end{tabular}

Respondents were asked whether westernization or modernization is gradually changing our cultural pattern, i.e., food, clothes, and education. About $8.5 \%$ of the respondents strongly disagreed, 9.2\% disagreed, $33.8 \%$ agreed, and $48.8 \%$ strongly agreed with the statement. However, most of the respondents were of the views that westernization and modernization are gradually changing our cultural patterns, i.e., $81 \%$ of the sample agree that modernization and westernization are changing our cultural patterns (Ballengee-Morris and Stuhr, 2001). 
Table 2: Percentage distribution of the need of western culture

\begin{tabular}{lll}
\hline Need of western culture & Frequency & Percentage \\
\hline Strongly disagree & 32 & 7.8 \\
\hline Disagree & 106 & 25.8 \\
\hline Agree & 202 & 49.1 \\
\hline Strongly agree & 71 & 17.3 \\
\hline Total & 411 & 100.0 \\
\hline
\end{tabular}

Respondents were also asked about the need for western culture in their context. The response of the respondents was varied as previously. About 7.8\% of the students strongly disagreed, 25.8\% disagreed, 49.1\% agreed, and $17.3 \%$ strongly agreed that the need for Western culture increased over time. With the change in material culture, the non-material culture also needs to be changed. In addition, people now think that there is a demand and need for western culture in Pakistan (Jahoda, 2018; Lake et al., 2000).

Table 3: Modernity and western influence

\begin{tabular}{lccc}
\hline Modernity & \multicolumn{3}{l}{ Western influence } \\
\cline { 2 - 4 } & Lower & Medium & Higher \\
\hline Lower & $67.0 \%$ & $22.4 \%$ & $30.0 \%$ \\
\hline Medium & $20.0 \%$ & $71.2 \%$ & $32.0 \%$ \\
\hline Higher & $13.0 \%$ & $6.3 \%$ & $38.0 \%$ \\
\hline Total & $100 \%$ & $100 \%$ & $100 \%$ \\
\hline $\mathrm{X}^{2}=285.78$ & $\mathrm{df}=4$ & Sig. $=.000$ & \\
\hline
\end{tabular}

The results indicated that less modern students experience lower western influence $(67 \%)$, and more modern students reported a higher level of western influence (38\%). In addition, the association between both the variables is very strong at about a $99 \%$ confidence interval. It means that a higher level of modernity will increase western influence among the students. The previous studies indicated that modernity, a way of thinking, influences the students' minds, and they start exhibiting western influence (Shaw,2014).

Table 4: Modernity and western education influence

\begin{tabular}{lccc}
\hline Modernity & \multicolumn{3}{c}{ Western education influence } \\
\cline { 2 - 4 } & Lower & Medium & Higher \\
\hline Lower & $62.0 \%$ & $25.4 \%$ & $2.8 \%$ \\
\hline Medium & $8.0 \%$ & $69.3 \%$ & $43.6 \%$ \\
\hline Higher & $30.0 \%$ & $5.4 \%$ & $53.6 \%$ \\
\hline Total & $100 \%$ & $100 \%$ & $100 \%$ \\
\hline $\mathrm{X}^{2}=211.38$ & df $=4$ & Sig. .000 & \\
\hline
\end{tabular}

The results indicated that less modern students experience lower educational influence (62\%), and more modern students reported a higher level of educational influence (53.6\%). In addition, the association between both the variables is very strong at about a $99 \%$ confidence interval. It means that a higher level of modernity will increase western educational influence among the students. These study findings are consistent with the previous studies on the topic, i.e., modernity and western educational influence (Cannizzo \& James, 2020).

\section{CONCLUSION}

It is pertinent to mention that modern global values are rapidly penetrating Pakistani society. These modern western values are somehow in contrast to the traditional values of Pakistani society. Pakistani youth enrolled in universities think that modernity and globalization had a very strong impression on people's lives. Globalization leads modernity and western culture to have a very strong impression on people's lives, and this strong impression is higher in urban areas than in rural areas. Therefore, it is changing every aspect of Pakistani culture, including food, clothes, and even educational institutions and systems. Westernization and its linked concept of modernity are gradually changing Pakistani culture to western culture, and more and more western values are now penetrating Pakistani society. It is also increasing flexibility among the educational institution of Pakistani like colleges and universities are now more flexible to promote those values which are similar to global western values.

\section{LIMITATION AND STUDY FORWARD}

The study is only conducted in public sector universities; modernity and cultural change might differ in private educational institutions. The general population's opinions might differ based on their socio-demographic characteristics like education and age. Generalizability of the findings of the present study on the general population is not possible because data is collected from highly educated young people and urbanized areas, i.e., Lahore and Faisalabad. 


\section{RECOMMENDATIONS}

Because of rapidly penetrating modernity and western values that are devaluing local culture, special needs are required to filter the beneficial and non-beneficial values to protect indigenous culture. Western dressing and branded clothes are now prevalent worldwide, and local dressing and clothes are not the people's preference. Therefore, it is necessary to change the modern Western outlook to local traditions. The use of modern technology, innovation, and applications facilitates humans. However, every type of technology that might devalue humans should not discourage at any matter.

\section{AUTHORS' CONTRIBUTIONS:}

Sidra Noreen: Data Collection, working on literature, writing references and after completion of research review the article.

Izhar Ahmad Khan: Data Collection, working on literature, writing references and after completion of research review the article.

Farkhanada Anjum: Data Collection, working on literature and after completing research, its review.

Ejaz Ashraf: Data Collection, working on literature and after completing research, its review.

\section{REFERENCES}

1. Abebe, T. (2007). Changing livelihoods, changing childhoods: patterns of children's work in rural southern Ethiopia. Children's Geographies, 5(1-2), 77-93. https://doi.org/10.1080/14733280601108205

2. Altbach, P. G., \& Knight, J. (2007). The internationalization of higher education: Motivations and realities. Journal of studies in international education,11(3-4), 290-305. https://doi.org/10.1177/10 28315307303542

3. Altbach, P. G., \& Knight, J. (2007). The internationalization of higher education: motivations and realities. Journal of studies in international education,11(4), 290-305. https://doi.org/10.1177 /1028315307303542

4. Amin, S. (2014). Capitalism in the age of globalization: The management of contemporary society. Zed Books Ltd.

5. Astrup, A., Dyerberg, J., Elwood, P., Hermansen, K., Hu, F. B., Jakobsen, M. U., \& Nestel, P. (2011). The role of reducing intakes of saturated fat in preventing cardiovascular disease: where does the evidence stand in 2010?. The American journal of clinical nutrition, 93(4), 684-688. https://doi.org/10.3945/ajcn.110.004622

6. Ballengee-Morris, C., \& Stuhr, P. L. (2001). Multicultural art and visual culture education in a changing world. Art Education, 54(4), 6-13. https://doi.org/10.2307/3193897

7. Bauman, Z. (2013). Wasted lives: Modernity and its outcasts. John Wiley \& Sons.

8. Bottomore, T. (2006). Culture emergent in occupation. American Journal of Occupational Macmillan, New York. Therapy, 58(2), 159-168.

9. Collins, C. S., Castro, A. R., \& Ryan, T. K. (2016). The Driving Forces of Higher Education: Westernization,

10. Confucianism, Economization, and Globalization. In The Palgrave Handbook of Asia Pacific Higher Education (pp. 279-291).

11. Cook, N. (2005). What to wear, what to wear?: Western women and imperialism in Gilgit, Pakistan. Qualitative Sociology, 28(4), 351-369. https://doi.org/10.1007/s11133-005-8363-4

12. Cui, X., \& Ryan, C. (2011). Perceptions of place, modernity and the impacts of tourism-Differences among rural and urban residents of Ankang, China: A likelihood ratio analysis. Tourism Management, 32(3), 604615. https://doi.org/10.1016/j.tourman.2010.05.012

13. Habib, Z. (2018). International Mindedness and Intercultural Competence: Perceptions of Pakistani Higher Education Faculty. Journal of Education and Educational Development, 5(1), 60-79. https://doi.org/10.2 2555/joeed.v5i1.1807

14. Hashim, M., Ullah, M., Khan, M.A., (2017). Impact of time flexibility on employees' performance: A study of teaching faculty in government colleges of management sciences Peshawar. City University Research Journal, 2(2), 34-47.

15. Hamid, M. O., \& Honan, E. (2012). Communicative English in the primary classroom: Implications for English-in-education policy and practice in Bangladesh. Language, Culture and Curriculum, 25(2), 139-156. https://doi.org/10.1080/07908318.2012.678854

16. Hussain, A., Zulfiqar, F., \& Saboor, A. (2014). Changing food patterns across the seasons in rural Pakistan: analysis of food variety, dietary diversity and calorie intake. Ecology of food and nutrition, 53(2), 119-141. https://doi.org/10.1080/03670244.2013.792076

17. Inglehart, R., \& Baker, W. E. (2000). Modernization, cultural change, and the persistence of traditional values. American sociological review, 19-51. https://doi.org/10.2307/2657288

18. Jahoda, G. (2018). Images of Savages: Ancient roots of modern prejudice in Western culture. Routledge. https://doi.org/10.4324/9781315787909

19. Kakar, Z. K., Khilji, B. A., \& Khan, M. J. (2011). Globalization and economic growth: Evidence from Pakistan. Acta Universitatis Danubius. Economica, 7(3). 
20. Kazmi, S. W., \& Quran, H. (2005). Role of education in globalization: A case for Pakistan. SAARC journal of human resource development, 1(1), 90-107.

21. Khan, H. I. (2014). Globalization and education. Journal of Education and Educational Development, 1(1), 67. https://doi.org/10.22555/joeed.v1i1.4

22. Khan, K. M., Ullah M. (2021). Mediating Role of Ethical Leadership Between Employees Empowerment and Competitive Edge: A Case of Commercial Banks in Pakistan. Humanities \& Social Sciences Reviews, 9(2), 219-231. https://doi.org/10.18510/hssr.2021.9223

23. Khan, A. M., Ullah, M., Usman, A., Malik, A. H., Khan, K. M. (2020). Impact of covid-19 on the global economy. International Journal of Management, 11(8), 2020, pp. 956-969.

24. Knight, J. (2007). Higher education in turmoil. The changing world of internationalization, 8. https://doi.org/10.1163/9789087905224

25. Lake, A. J., Staiger, P. K., \& Glowinski, H. (2000). Effect of Western culture on women's attitudes to eating and perceptions of body shape. International Journal of Eating Disorders, 27(1), 83-89. https://doi.org/10.1002/(SICI)1098-108X(200001)27:1<83::AID-EAT9>3.0.CO;2-J

26. Lee, M. N. (2013). Globalization practices in Asia Pacific universities. In The Dynamics of Higher Education

27. Development in East Asia (pp. 161-178). Palgrave Macmillan, New York. https://doi.org/10.1057/9 $781137347374 \quad 9$

28. Luomala, H., Jokitalo, M., Karhu, H., Hietaranta-Luoma, H. L., Hopia, A., \& Hietamäki, S. (2015). Perceived health and taste ambivalence in food consumption. Journal of Consumer Marketing. https://doi.org/10.1108/JCM-11-2014-1233

29. Malik, R., Hammad, M., Irshad, N., Chughtai, B. R., \& Masood, R. (2020). Domestic violence in Rawalpindi. Journal of Rawalpindi Medical College, 24(1), 18-22. https://doi.org/10.37939/jrmc/vol24.iss1.5

30. Maqsood, A. (2014). 'Buying Modern' Muslim subjectivity, the West and patterns of Islamic consumption in Lahore, Pakistan. Cultural Studies, 28(1), 84-107. https://doi.org/10.1080/09502386.2013.771691

31. Neubauer, D. (2013). The globalized university is the next stage in Higher Education Development. In The Dynamics of Higher Education Development in East Asia (pp. 133-159). Palgrave Macmillan, New York. https://doi.org/10.1057/9781137347374_8

32. Shaw, A. (2014). Kinship and Continuity: Pakistani families in Britain. Routledge. https://doi.org/10.4324/9 781315080062

33. Torres, C. A. (2002). The State, Privatisation and Educational Policy: a critique of neoliberalism in Latin America and some ethical and political implications. Comparative Education, 38(4), 365-385. https://doi.org/10.1080/0305006022000030766

34. Triandis,(2018). Cultural theory and risk: a review. Health, risk \& society, 1(1), 71-90. https://doi.org/10.1080/13698579908407008

35. Ullah, M. (2020). Women empowerment and social development in Afghanistan through microfinance. International Journal of Academic Research in business and Social Sciences, 10(12), 377-389. https://doi.org/10.6007/IJARBSS/v10-i12/8324

36. Varnum, M. E., \& Grossmann, I. (2017). Cultural change: The how and the why. Perspectives on Psychological Science, 12(6), 956-972. https://doi.org/10.1177/1745691617699971

37. Willis , J. (2003). Modernization and traditional values. American sociological review, 12(4), $143-151$. 